\title{
PREVALENSI KASUS DEMAM BERDARAH DENGUE DI RUMAH SAKIT UMUM PUSAT SANGLAH DENPASAR PERIODE JUNI-NOVEMBER 2014
}

\author{
Arvinth Ganesan \\ Fakultas Kedokteran Universitas Udayana \\ (arvin_3682@hotmail.com)
}

\section{ABSTRAK}

Demam berdarah Dengue atau juga disebut sebagai "breakbone fever" adalah infeksi yang disebabkan oleh virus dengue dan penularan melalui gigitan nyamuk aedes.Demam berdarah Dengue merupakan penyakit demam akut yang disertai dengan adanya manifestasi pendarahan, yang bertendensi mengakibatkan renjatan yang dapat menyebabkan kematian. Tujuan utama penelitian ini adalah untuk menyelidiki dan menganalisis prevalensi kasus demam berdarah dengue yang telah dilaporkan di Rumah Sakit Umum Pusat Sanglah Denpasar dari bulan Juni sehingga November pada tahun 2014. Desain penelitian yang digunakan untuk studi ini adalah studi deskriptif kohort retrospektif. Penelitian ini melibatkan pasien di Rumah Sakit Umum Pusat Sanglah, Denpasar, yang telah didiagnosis dengan kasus demam berdarah dengue. Penelitian ini dilakukan menggunakan data dari 429 rekam medis iaitu 118 kasus rawat jalan dan 311 kasus rawat inap. Berdasarkan hasil penelitian ini didapatkan bahwa persentase kasus tertinggi adalah pada bulan Juni dengan 28.20\%.Persentase ini diikuti dengan Juli sebanyak 22.14\%, Agustus sebanyak $15.62 \%$, September sebanyak $11.89 \%$, Oktober sebanyak $11.42 \%$, dan hanya $10.73 \%$ pada bulan November. Interpretasi menunjukkan bahawa prevalensi demam berdarah dengue yang dilaporkan di RSUP Sanglah dari bulan Juni - November 2014 semakin berkurang langkah demi langkah. Diharapkan penelitian ini berguna bagi tatalaksana prevalensi demam berdarah dengue pada masa hadapan.

Kata Kunci: Demam Berdarah Dengue, RSUP Sanglah, Rekam Medis, Prevalensi

\begin{abstract}
Dengue fever, also known as breakbone fever, is a mosquito-borne infection that causes a severe flu-like illness. Dengue can vary from mild to severe; the more severe forms include dengue shock syndrome and dengue haemorrhagic fever (DHF).The main purpose of this research is to investigate and analyse the prevalence of dengue cases that has been reported in Rumah Sakit Umum Pusat Sanglah, Denpasar from the month of June to November in the year of 2014. The design research used for this study is Descriptive study of cohort retrospective. The target population is basically the population of patients in Rumah Sakit Umum Pusat Sanglah, Denpasar, who has been diagnosed with dengue fever. This research is carried out using medical data of 429 patients. Total of 118 cases are reported as outpatients and 311 cases are inpatient. Based on the research, the highest percentage of case reported is in the month of June with $28.20 \%$ of total cases. The percentage is then followed by $22.14 \%$ in July, 15.62 in August, $11.89 \%$ in September, $11.42 \%$ in October, and only $10.73 \%$ in November. Conclude can be made that prevalence of dengue fever which has been reported in RSUP Sanglah from the month of June to November 2014 has been decreasing step by step. It is hoped this study will be useful for the control of dengue cases in the future.
\end{abstract}

Keyword: Dengue Fever, RSUP Sanglah, Medical Data, Prevalence

\section{PENDAHULUAN}

\section{Latar Belakang Penelitian}

Kemunculan dan re-emergence penyakit menular melibatkan banyak factor yang saling terkait.Keterkaitan global terus meningkat dengan perjalanan internasional dan perdagangan; ekonomi, politik, dan budaya dan interaksi manusia ke manusia atau binatang ke manusia .Interaksi ini termasuk disengaja dan tidak disengaja berbagi mikroba agen dan antimicrobial perlawanan dan memungkinkan kemunculan penyakit baru dan agen mikroba yang tidak dikenali.Seperti abad 21 dimulai, agen baru telah diidentifikasi, dan wabah baru telah terjadi. 
Organisasi Kesehatan Dunia melaporkan bahwa sekitar 50 juta orang yang terinfeksi dengan dengue, meskipun beberapa peneliti memperkirakan bahwa jumlah ini bisa setinggi 100 juta. Biasanya, demam berdarah menyebabkan sakit seperti demam, sakit kepala, dan berat badan menurun dan nyeri sendi. Kebanyakan pasien sembuh dari infeksi dengue.

Dalam beberapa tahun terakhir jumlah kasus demam berdarah dilaporkan kepada organisasi kesehatan dunia telah meningkat secara dramatis.Demam berdarah telah menjadi ancaman kesehatan untuk masyarakat yang lebih besar daripada yang telah di masa lalu.Epidemi telah terjadi di hampir semua beberapa daerah tropis dan subtropis dunia.Demam berdarah sudah menyebar ke negara baru, termasuk Nepal dan Bhutan, dan insiden berdarah thirty-fold telah meningkat sejak tahun 1960an.

Asal-usul demam berdarah adalah tidak jelas, tapi para ilmuwan baru-baru ini mengusulkan bahwa berasal di hutan Asia dalam sebuah siklus menular melibatkan nyamuk dan primata. Seperti awal sebagai 992, merebaknya sebuah dengue-like pada manusia saja yang terekam dalam encyclopaedia China.Epidemik tersebut dari dengue-like dilaporkan telah menjangkit di Barat Perancis pada tahun 1635 dan di Panama pada tahun 1699.

Saat ini tidak ada vaksin untuk penyakit demam berdarah dengue.Cara terbaik untuk mencegah penyakit ini untuk menghindari yang digigit nyamuk.Meskipun tidak ada pengobatan untuk demam berdarah, tertentu itu dapat diobati selama itu tertangkap sebelum berkembang menjadi berdarah dengue atau demam berdarah dengue shock syndrome haemorrhagic.

Demam berdarah dengue dapat umumnya ditemukan di Kota bagian dari daerah tropis dan subtropis, seperti tengah dan Amerika selatan, tempat di Afrika bagian dari Asia, karibia dan pasifik.

\section{Rumusan Masalah}

Berdasarkan uraian yang telah dikemukakan pada latar belakang penelitian, maka rumusan masalah pada penelitian ini adalah:

1. Berapakah prevalensi kasus berdarah dengue yang telah dilaporkan?

\section{Tujuan Penelitian}

\section{- Tujuan Umum}

Untuk mengetahui jumlah kasus demam berdarah dengue yang telah dilaporkan di Rumah Sakit Umum Pusat Sanglah Denpasar.

\section{- Tujuan Khusus}

Untuk menyelidiki dan menganalisis prevalensi kasus demam berdarah dengue yang telah dilaporkan di Rumah Sakit Umum Pusat Sanglah Denpasar.

\section{Manfaat Penelitian}

1) Mengetahui prevalensi jumlah kasus demam berdarah dengue yang telah dilaporkan.

2) Memberikan informasi kepada praktisi kesehatan terutama di Rumah Sakit Umum Pusat Sanglah Denpasar mengenai karakteristik dan memicu daripada laporan kasus yang baru.

\section{Kajian Pustaka}

\section{Definisi}

Dengue adalah virus yang paling umum (arboviral) penyakit pada manusia arthropodaditanggung. Secara global, 2, 5-3 billion orang tinggal di sekitar 112 negara yang mengalami transmisi dengue. Setiap tahun, sekitar 50-100 juta orang terinfeksi. Hal ini disebabkan oleh infeksi 1 dari 4 serotipe virus dengue, yang merupakan virus flavi (genus beruntai tunggal tidak ada virus RNA tersegmentasi). Infeksi dengan satu serotipe dengue menganugerahkan kekebalan seumur hidup homotypic dengan serotipe dan waktu yang sangat singkat heterotypic kekebalan parsial terhadap serotipe lain, tetapi seseorang akhirnya dapat terinfeksi oleh semua 4 serotipe. Beberapa serotipe dapat beredar selama epidemi. (Bandyopadhyay S, Lum LC, Kroeger A.2006)

Demam berdarah klasik, ditandai dengan onset akut demam tinggi 3-14 hari setelah gigitan nyamuk yang terinfeksi. Gejala termasuk sakit kepala frontal, retro-orbital nyeri, manifestasi perdarahan, ruam, dan jumlah sel darah putih yang rendah. Pasien juga mungkin mengeluhkan anoreksia dan mual. Gejala akut, jika ada, biasanya berlangsung sekitar 1 minggu, tapi kelemahan, malaise, dan anoreksia dapat bertahan selama beberapa minggu. Sebagian besar dari infeksi dengue tidak menghasilkan gejala atau gejala minimal, terutama pada anak-anak dan mereka yang tidak memiliki riwayat memiliki infeksi dengue.

\section{Patofisiologi}

Virus dengue ditularkan melalui gigitan Nyamuk Aedes yang terinfeksi. Mereka biasanya menggigit manusia dan hanya menyebabkan ruam kecil, namun, beberapa gigitan dapat menyebabkan infeksi serius. Demam berdarah biasanya ditemukan di lingkungan tropis atau subtropis. Paparan infeksi dapat mengakibatkan demam berdarah ringan. Kasus demam 
berdarah dengue atau dengue shock syndrome. Seseorang menjadi terinfeksi ketika nyamuk yang terinfeksi menggigit mereka dan ada pertukaran darah. Juga, orang dapat terinfeksi jika ada pertukaran darah dengan seseorang yang sudah memiliki virus. Patofisiologi demam berdarah dengue termasuk demam mendadak, sakit kepala parah, mialgia, artralgia ini, leukopenia, trombositopenia dan manifestasi perdarahan. (Anderson K et al. 2007)

Dalam beberapa kasus orang mengalami syok dan perdarahan, yang bisa berakibat fatal. Penyakit ini disebabkan oleh salah satu dari 4 virus terkait, yaitu DEN-1, DEN-2, DEN-3, dan DEN-4. Gejala-gejala ini berkembang setelah masa inkubasi, yaitu sekitar 5-8 hari. Gejala ini dengan cepat akan muncul pada pasien. Pasien biasanya menderita lonjakan demam selama 48 sampai 96 jam. Demam akan mereda selama beberapa hari tapi kembali tinggi. Ketika ini terjadi, ruam biasanya muncul di atas anggota badan pasien.

\section{Etiologi}

Infeksi dengue disebabkan oleh virus dengue (DENV), yang merupakan virus RNA beruntai tunggal (sekitar 11 kilobases panjang) dengan nukleokapsid ikosahedral dan ditutupi oleh amplop lipid. Virus ini dalam keluarga Flaviviridae, genus Flavivirus, dan virusjenis tertentu adalah demam kuning. Virus dengue punya 4 terkait tetapi serotipe antigen yang berbeda: DENV-1, DENV-2, DENV-3, dan DENV-4. Studi genetik strain sylvatic menunjukkan bahwa 4 serotipe berevolusi dari nenek moyang yang sama pada populasi primata sekitar 1000 tahun yang lalu dan bahwa semua 4 secara terpisah muncul ke dalam siklus penularan perkotaan manusia 500 tahun yang lalu, baik di Asia atau Afrika. Setiap serotipe dikenal memiliki beberapa genotipe. Viral genotipe dan serotipe, dan urutan infeksi dengan serotipe yang berbeda, tampaknya mempengaruhi keparahan penyakit. (Halstead SB 2006)

\section{Prognosa}

Demam berdarah biasanya penyakit selflimiting dengan angka kematian kurang dari 1\%. Ketika diobati, demam berdarah dengue memiliki tingkat kematian sebesar 2-5\%. Ketika tidak diobati, demam berdarah dengue memiliki tingkat kematian setinggi $50 \%$.

Selamat biasanya sembuh tanpa gejala sisa dan mengembangkan kekebalan terhadap serotipe yang menginfeksi. Faktor-faktor yang mempengaruhi keparahan penyakit meliputi berikut ini:

- Usia pasien

- Kehamilan

- Status gizi

- Urutan infeksi dengan serotipe dengue yang berbeda
- Genotipe Virus

Komplikasi dan menjerit infeksi virus dengue jarang tapi mungkin termasuk yang berikut:

- Cardiomyopathy

- Kejang, ensefalopati

- Depresi

- Pneumonia

\section{Tahap}

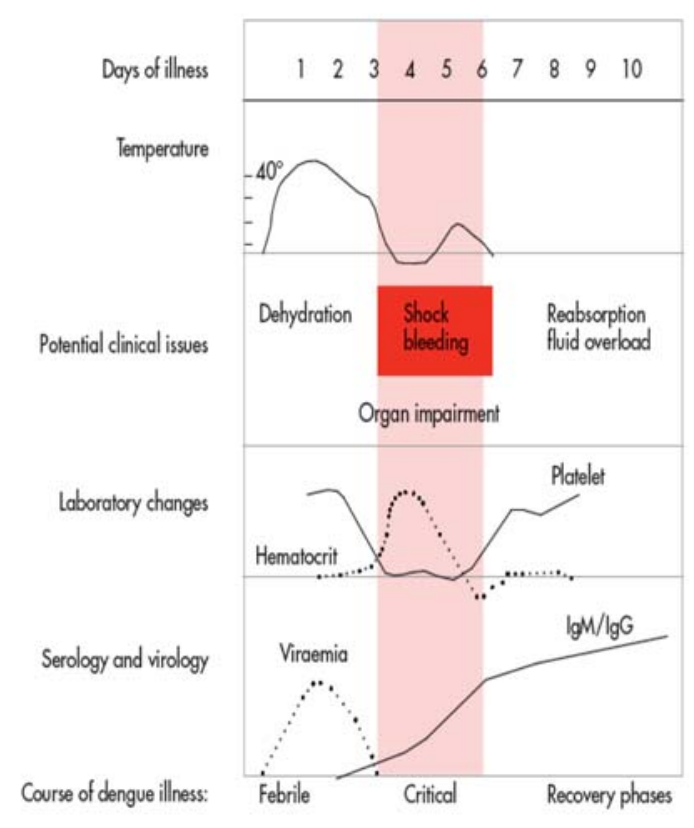

Diagram 2.5 - Kursus penyakit dengue

\section{Fasa Demam}

Pasien biasanya mengalami demam bermutu tinggi tiba-tiba. Fase demam akut ini biasanya berlangsung 2-7 hari dan sering disertai dengan kemerahan pada wajah, eritema kulit, umum sakit badan, mialgia, artralgia dan sakit kepala. Beberapa pasien mungkin memiliki sakit tenggorokan, disuntikkan faring dan injeksi konjungtiva. Anoreksia, mual dan muntah yang umum. Ini bisa sulit untuk membedakan DBD klinis dari penyakit demam nondengue pada fase demam awal. Sebuah tes tourniquet positif dalam fase ini meningkatkan kemungkinan dengue.Selain itu, fitur klinis yang bisa dibedakan antara kasus dengue yang parah dan tidak parah. Oleh karena itu pemantauan untuk tanda-tanda peringatan dan parameter klinis lain sangat penting untuk mengenali perkembangan ke fase kritis. Manifestasi perdarahan ringan seperti membran mukosa petechial dan perdarahan (misalnya hidung dan gusi) dapat dilihat. Perdarahan vagina besar (pada wanita usia subur) dan perdarahan gastrointestinal dapat terjadi selama fase ini tetapi tidak umum. Hati sering membesar dan lembut setelah beberapa hari demam. 
Awal kelainan pada hitung darah lengkap adalah penurunan progresif total jumlah sel putih.

\section{Fasa Kritis}

Sekitar waktu penurunan suhu badan sampai yg normal, ketika suhu turun ke 37.5-38oC atau kurang dan tetap di bawah tingkat ini, biasanya pada hari 3-7 sakit, permeabilitas kapiler meningkat secara paralel dengan peningkatan kadar hematokrit dapat terjadi. Ini tanda awal dari fase kritis. Periode kebocoran plasma yang bermakna secara klinis biasanya berlangsung 2448 jam. Leukopenia progresif diikuti oleh penurunan cepat dalam jumlah trombosit biasanya mendahului kebocoran plasma. Pada titik ini pasien permeabilitas kapiler akan meningkat, sementara mereka dengan peningkatan permeabilitas kapiler dapat menjadi lebih buruk sebagai akibat dari volume plasma yang hilang. Tingkat kebocoran plasma bervariasi. Efusi pleura dan ascites mungkin secara klinis terdeteksi tergantung pada tingkat kebocoran plasma dan volume terapi cairan. Oleh karena itu x-ray dada dan USG perut dapat menjadi alat yang berguna untuk diagnosis. Tingkat kenaikan di atas hematokrit awal sering mencerminkan keparahan kebocoran plasma. Syok terjadi ketika volume kritis plasma hilang melalui kebocoran. Hal ini sering didahului oleh tanda-tanda peringatan. Suhu tubuh mungkin subnormal ketika guncangan terjadi. Dengan syok berkepanjangan, hipo organ hasil perfusi konsekuen dalam gangguan organ progresif, asidosis metabolik dan koagulasi intravaskular. Hal ini pada gilirannya menyebabkan perdarahan yang parah menyebabkan hematokrit menurun shock berat. Alihalih leukopenia biasanya terlihat selama fase ini demam berdarah, total jumlah sel darah putih dapat meningkatkan pada pasien dengan perdarahan hebat. Selain itu, gangguan organ berat seperti hepatitis berat, ensefalitis atau miokarditis dan / atau pendarahan parah juga dapat berkembang tanpa kebocoran plasma yang jelas atau syok.

\section{Fasa Pemulihan}

Jika pasien bertahan fase kritis 24-48 jam, reabsorpsi bertahap cairan kompartemen ekstravaskuler terjadi dalam 48-72 jam berikutnya. Kesejahteraan umum membaik, nafsu makan kembali, gejala gastrointestinal mereda, status hemodinamik stabil dan diuresis terjadi kemudian. Beberapa mungkin mengalami pruritus umum. Bradikardia dan elektrokardiografi perubahan yang umum selama tahap ini. Hematokrit stabil atau mungkin lebih rendah karena efek dilusi cairan diserap. Jumlah sel darah putih biasanya mulai naik segera setelah penurunan suhu badan sampai yg normal tetapi pemulihan jumlah trombosit biasanya lebih lambat dibandingkan dengan jumlah sel darah putih. Distres pernapasan dari efusi pleura masif dan ascites akan terjadi kapan saja jika cairan intravena yang berlebihan telah diberikan. Selama fase kritis dan / atau pemulihan, terapi cairan yang berlebihan berhubungan dengan edema paru atau gagal jantung kongestif.

\section{Fasa Parah}

Dengue yang parah didefinisikan oleh satu atau beberapa hal berikut: (I) Plasma kebocoran yang dapat menyebabkan syok (dengue shock) dan / atau akumulasi cairan, dengan atau tanpa gangguan pernapasan, dan / atau (II) Pendarahan hebat, dan / atau (III) gangguan organ parah. Selama pembuluh darah dengue berlangsung, hipovolemia memburuk dan munkin berlaku shock. Ini biasanya terjadi di sekitar penurunan suhu badan sampai yang normal, biasanya pada hari ke-4 atau 5 (kisaran 3-7 hari) sakit, didahului oleh tanda-tanda peringatan. Selama tahap awal shock, mekanisme kompensasi yang mempertahankan tekanan darah sistolik yang normal juga menghasilkan takikardia dan vasokonstriksi perifer dengan mengurangi perfusi kulit. Pasien dianggap memiliki kejutan jika tekanan nadi (yaitu perbedaan antara tekanan sistolik dan diastolik) adalah $\leq 20 \mathrm{~mm} \mathrm{Hg}$ pada anak-anak atau memiliki tanda-tanda perfusi kapiler miskin (ekstremitas dingin, tertunda pengisian kapiler, atau denyut nadi cepat rate). Pada orang dewasa, tekanan nadi $\leq 20 \mathrm{~mm} \mathrm{Hg}$ dapat menunjukkan kejutan yang lebih parah.

Hipotensi biasanya dikaitkan dengan syok berkepanjangan yang sering diikuti dengan pendarahan.

Pasien dengan demam berdarah yang parah mungkin memiliki kelainan koagulasi, tetapi ini biasanya tidak cukup untuk menyebabkan pendarahan besar. Ketika pendarahan besar tidak terjadi, itu hampir selalu dikaitkan dengan kejutan besar karena ini, dalam kombinasi dengan trombositopenia, hipoksia dan asidosis, dapat menyebabkan gagal organ multiple dan maju disseminated intravascular coagulation. Perdarahan masif dapat terjadi tanpa syok berkepanjangan dalam kasus ketika asam asetilsalisilat (aspirin), ibuprofen atau kortikosteroid telah diambil.

Manifestasi yang tidak biasa, termasuk gagal hati akut dan ensefalopati, mungkin ada, bahkan tanpa adanya kebocoran plasma berat atau syok. Cardiomyopathy dan ensefalitis juga dilaporkan dalam kasus demam berdarah beberapa. Namun, sebagian besar kematian akibat DBD terjadi pada pasien dengan syok yang mendalam, terutama jika situasi rumit oleh kelebihan cairan.

Dengue yang parah harus dipertimbangkan jika pasien dari daerah risiko DBD yang mengalami demam 2-7 hari ditambah salah satu fitur berikut: 
- Ada bukti kebocoran plasma, seperti:

- Tinggi atau progresif meningkat hematokrit;

- Efusi pleura atau ascites;

- Ada tingkat kesadaran yang berubah (letargi atau gelisah, koma, kejang).

- Ada keterlibatan parah gastrointestinal (muntah terus-menerus, meningkatkan atau sakit perut yang intens, sakit kuning).

- Ada penurunan berat organ (gagal hati akut, gagal ginjal akut, ensefalopati atau ensefalitis, atau manifestasi lain yang tidak biasa, kardiomiopati) atau manifestasi yang tidak biasa lainnya.

\section{Diagnosa}

\section{Diagnosa klinis}

Beberapa pasien dengan demam berdarah terus mengembangkan demam berdarah dengue (DBD), bentuk parah dan kadang-kadang fatal penyakit. Sekitar waktu demam mulai mereda (biasanya 3-7 hari setelah timbulnya gejala), pasien dapat mengembangkan tanda-tanda peringatan dari penyakit yang berat. Tanda-tanda peringatan termasuk sakit parah perut, muntah terus menerus, ditandai perubahan suhu (demam hipotermia), manifestasi perdarahan, atau perubahan status mental (mudah marah, kebingungan, atau obtundation). Pasien juga mungkin memiliki tanda-tanda awal syok, termasuk kegelisahan, kulit lembab dan dingin dingin, nadi lemah cepat, dan penyempitan tekanan nadi (tekanan darah sistolik - tekanan darah diastolik). Pasien demam berdarah harus diberitahu untuk kembali ke rumah sakit jika mereka mengembangkan salah satu dari tanda-tanda ini.

DBD saat ini didefinisikan oleh empat Organisasi Kesehatan Dunia (WHO) kriteria sebagai berikut:

- Demam atau sejarah demam berlangsung 2-7 hari.

- Setiap manifestasi perdarahan.

- (jumlah trombosit dari <100.000 / mm3) Trombositopenia.

- Bukti peningkatan permeabilitas pembuluh darah. Manifestasi perdarahan yang paling umum adalah ringan dan termasuk tes positif tourniquet, perdarahan kulit (petechiae, hematoma), epistaksis (mimisan), perdarahan gingiva (gusi berdarah), dan hematuria mikroskopik.

- Peningkatan hematokrit $\geq 20 \%$ di atas rata-rata populasi hematokrit untuk usia dan jenis kelamin.
- Penurunan hematokrit setelah pengobatan volume penggantian $\geq 20 \%$ dari hematokrit awal.

- Adanya efusi pleura atau ascites terdeteksi oleh radiografi atau metode pencitraan lainnya.

- Hypoproteinemia atau hipoalbuminemia yang ditentukan oleh uji laboratorium.

\section{Diagnosa Laboraturium}

Diagnosis tegas infeksi dengue membutuhkan laboratorium konfirmasi, baik dengan mengisolasi virus atau mendeteksi antibodi-dengue spesifik. Untuk isolasi virus atau deteksi DENV RNA dalam spesimen serum oleh-serotipe spesifik, real-time membalikkan reaksi transcriptase polymerase chain (RT-PCR), sebuah fase akut spesimen serum harus dikumpulkan dalam waktu 5 hari dari onset gejala. Jika virus tidak dapat dipisahkan atau terdeteksi dari sampel ini, sembuh-fase spesimen serum yang dibutuhkan setidaknya 6 hari setelah timbulnya gejala untuk membuat diagnosis serologi dengan tes antibodi IgM untuk demam berdarah dengan IgM antibodi-capture enzyme-linked immunosorbent assay (MAC-ELISA).

Fase akut dan sampel serum sembuh-tahapan yang harus dikirim ke departemen kesehatan negara atau tertalu Pusat Pengendalian dan Pencegahan Penyakit (CDC) untuk pengujian. Sampel fase akut untuk diagnosis virus dapat disimpan pada es kering ($\left.70^{\circ} \mathrm{C}\right)$ atau jika pengiriman dapat dilakukan dalam waktu 1 minggu, disimpan dicairkan di kulkas $\left(4^{\circ} \mathrm{C}\right)$. Sampel sembuh-tahapan yang harus dikirim dalam wadah kaku tanpa es, jika pengiriman pada hari berikutnya terjamin. Jika tidak, mereka harus dikirim di atas es dalam wadah terisolasi untuk menghindari paparan panas selama transit.

Sebagian besar tes untuk antibodi anti-dengue menghasilkan hasil spesifik untuk flavi virus, termasuk West Nile dan St. Louis virus ensefalitis. Karena kit komersial dapat bervariasi dalam sensitivitas dan spesifisitas, hasil tes mungkin perlu dikonfirmasi oleh laboratorium rujukan.

\section{Manajemen}

Demam berdarah biasanya penyakit pemulihan sendiri. Tidak ada pengobatan antivirus spesifik yang tersedia saat ini untuk demam berdarah. Perawatan suportif dengan analgesik, penggantian cairan, dan istirahat di tempat tidur biasanya cukup. Acetaminophen dapat digunakan untuk mengobati demam dan meredakan gejala lainnya. Aspirin, obat anti-inflamasi (NSAID), dan kortikosteroid harus dihindari. Pengelolaan dengue yang parah memerlukan perhatian untuk manajemen cairan dan pengobatan proaktif dari perdarahan.

\section{Kerangka Berpikir}


Dengue adalah infeksi nyamuk ditemukan di daerah tropis dan sub-tropis di seluruh dunia. Dalam beberapa tahun terakhir, transmisi telah meningkat terutama di daerah perkotaan dan semi-perkotaan dan telah menjadi masalah kesehatan masyarakat yang utama internasional. Dengue yang parah (sebelumnya dikenal sebagai Demam Berdarah Dengue) pertama kali diakui pada tahun 1950 selama wabah demam berdarah di Filipina dan Thailand. Hari ini, demam berdarah yang parah mempengaruhi sebagian besar negara Asia dan Amerika Latin dan telah menjadi penyebab utama rawat inap dan kematian.

Ada empat serotipe yang berbeda, tetapi terkait erat, virus yang menyebabkan demam berdarah (DEN-1, DEN-2, DEN-3 dan DEN-4). Pemulihan dari infeksi oleh satu memberikan kekebalan seumur hidup terhadap serotipe yang tertentu. Namun, crosskekebalan terhadap serotipe lain setelah pemulihan hanya parsial dan temporer. Infeksi berikutnya oleh serotipe lain meningkatkan risiko mengembangkan berdarah parah. Insiden berdarah telah tumbuh secara dramatis di seluruh dunia dalam beberapa dekade terakhir. Lebih dari 2,5 miliar orang - lebih dari $40 \%$ dari populasi dunia - sekarang menghadapi risiko dari dengue. WHO saat ini memperkirakan mungkin ada 50100 juta infeksi dengue di seluruh dunia setiap tahun.

Sebelum 1970, hanya sembilan negara telah mengalami epidemi dengue yang parah. Penyakit ini sekarang endemik di lebih dari 100 negara di Afrika, Amerika, Mediterania Timur, Asia Tenggara dan Pasifik Barat. Amerika, Asia Tenggara dan daerah Pasifik Barat paling terkena dampak serius.

Berdasarkan data dari badan kesehatan, 5.870 kasus DBD terjadi di pulau Bali pada tahun 2013, dengan Denpasar memukul dengan angka tertinggi pada 1,682 kasus dan diikuti oleh Kabupaten, Buleleng, Badung dan Gianyar juga melihat tinggi jumlah kasus DBD. Prevalensi DBD mencapai 145 orang per 100.000 penduduk. Bali memiliki populasi 4,1 juta. Sementara itu, angka kematian untuk wabah demam berdarah mencapai 1 persen dari total kasus pada tahun 2013.

\section{Rancangan Penelitian}

Desain penelitian yang digunakan untuk studi ini adalah studi cross sectional. Dalam penelitian cross sectional ini, peneliti hanya mengobservasi fenomena pada satu titik waktu tertentu. Penelitian hanya bersifat eksploratif ataupun eksplanatif. Penelitian cross sectional mampu menjelaskan hubungan satu variabel dengan variabel lain pada populasi yang diteliti, menguji keberlakuan suatu model atau ramuan hipotesis serta tingkat perbedaan di antara kelompok sampling pada satu titik waktu tertentu.

\section{Subjek dan Sampel}

\section{Populasi}

Populasi sasaran pada dasarnya adalah populasi di mana penelitian akan dilakukan. Penelitian ini melibatkan pasien di Rumah Sakit Umum Pusat Sanglah, Denpasar, yang telah didiagnosis dengan kasus demam berdarah

\section{Kriteria Sampel}

Sampel adalah pasien yang telah dilaporkan menderita DBD di RSUP Sanglah pada 6 bulan terakhir sebelum penelitian.

\section{Besar Sampel}

Besar sampel penelitian ini adalah semua data yang diperoleh sesuai dengan kriteria sampel. Peneliti mengumpulkan 429 data penderita Demam Berdarah Dengue melalui rekam medis data. Data ini adalah kasus dalam jangka masa 6 bulan.

\section{Teknik Pengambilan Data}

Data penelitian yang merupakan rekam medis masa lalu pasien yang menderita demam berdarah secara langsung diambil dari RSUP Sanglah.

\section{Variabel \\ Definisi Operasional Variabel}

1. Tempat kunjungan di mana pasien mungkin telah terinfeksi selama perjalanan.

- Bali

- Di Luar Bali

2. Jenis kelamin adalah ciri khas tertentu yang dimiliki penderita AIDS yang telah sesuai tercatat dalam kartu rekam medis. Jenis kelamin dikategorikan atas :

- Laki-laki

- Perempuan

3. Rawat inap (opname) adalah istilah yang berarti proses perawatan pasien oleh tenaga kesehatan profesional akibat penyakit tertentu, di mana pasien diinapkan di suatu ruangan di rumah sakit. Rawat jalan adalah pelayanan medis kepada seorang pasien untuk tujuan pengamatan, diagnosis, pengobatan, rehabilitasi, dan pelayanan kesehatan lainnya.

- Rawat Inap

- Rawat Jalan

4. Umur adalah usia penderita yang telah sesuai tercatat pada kartu rekam medis pasien. Umur dikategorikan berdasarkan :
- <20 Tahun
- 20-40 Tahun
- 40 Tahun 


\section{Bahan dan Instrumen Penelitian}

1) Rekam medis pasien yang telah didiagnosis dengan demam berdarah di RSUP Sanglah Denpasar pada 6 bulan terakhir sebelum penelitian.

2) Alat Tulis

3) Buku panduan proposal penelitian yang ditulis

4) Laptop

\section{Protokol Penelitian}

Protokol atau prosedur penelitian ini dibagi menjadi komponen yang merupakan tahap persiapan, tahap pelaksanaan dan tahap analisis.

a) Tahap Persiapan

Pada tahap persiapan, proposal penelitian dilakukan bersama-sama dengan surat rekomendasi untuk dikirim ke $R$ \& D untuk mengumpulkan data.Letter dikirim untuk persetujuan clearance.Upon etika pengajuan izin etis persiapan yang berlangsung untuk persetujuan dari Direktur Utama RSUP Sanglah dan departemen Diklat RSUP Sanglah

b) Tahap Pelaksanaan

Tahap implementasi dilakukan atas persetujuan dari Diklat RSUP Sanglah untuk melakukan penelitian. Pada tahap ini, rekam medis pasien dengan dengue diturunkan berdasarkan kriteria dan analysation sampel.

c) Tahap Analisis

Tahap analisis dilakukan setelah mengumpulkan catatan medis. Setelah analisis, pengaturan akhir dari laporan ini dilakukan sampai selesai.

\section{Analisis Data}

Data dari rekam medis adalah data sekunder. Data dikumpulkan dan dianalisis. Kemudian data akan diolah dan dianalisa dalam bentuk Bar chart.

\section{Kelemahan Penelitian}

Melakukan studi retrospektif tidak dapat mengendalikan paparan atau penilaian hasil, melainkan harus bergantung pada orang lain untuk akurat pencatatan. Hal ini sangat bermasalah karena bisa sangat sulit untuk membuat perbandingan yang akurat antara terpapar dan tidak terpapar. Penelitian ini juga membutuhkan ukuran sampel yang sangat besar untuk hasil yang jarang.

\section{Laporan Demam Berdarah Dengue periode Juni hingga November 2014}

Hasil penelitian ini dilakukan menggunakan data dari 429 rekam medis. Semua data yang dimasukkan dalam penelitian ini adalah pasien demam berdarah dari RSUP Sanglah yang pertama kali dievaluasi untuk kriteria inklusi dan eksklusi di bulan Juni hingga November.
Penelitian dan hasil laporan ini adalah kombinasi dari pasien rawat inap dan rawat jalan.Rawat inap (opname) adalah istilah yang berarti proses perawatan pasien oleh tenaga kesehatan profesional akibat penyakit tertentu, di mana pasien diinapkan di suatu ruangan di rumah sakit. Rawat jalan adalah pelayanan medis kepada seorang pasien untuk tujuan pengamatan, diagnosis, pengobatan, rehabilitasi, dan pelayanan kesehatan lainnya.Hasil penelitian rekam medis menunjukkan sebanyak 118 kasus rawat jalan dan 311 kasus rawat inap.

Berdasarkan data dari rekam medis pada 6 bulan terakhir, 429 kasus DBD dilapor di RSUP Sanglah dengan Denpasar memukul dengan angka tertinggi pada 243 kasus dan diikuti oleh Badung sebanyak 82 kasus, Gianyar 38 kasus, Karangasem 18 kasus, Buleleng 13 kasus, Tabanan 12 kasus, Klungkung 7 kasus, Negara 6 kasus dan Bangli 5 kasus.

Di Bali, musim hujan sejak dari selama bulan Desember dan Januari berlangsung hingga April. Selama periode ini, Bali tetap lembab, kelembaban relatif rata-rata $85 \%$. Curah hujan juga menyiratkan dengan $280 \mathrm{~mm}$ $300 \mathrm{~mm}$ bulanan dari bulan Desember sampai Februari. Sepanjang musim hujan, panas tetap pada puncaknya dan hujan membawa efek pendinginan tetapi meningkatkan kelembaban. April adalah bulan terpanas dengan kelembaban jatuh menjadi sekitar 65$70 \%$ dan suhu rata-rata maksimal sebesar 33 ․ C.

Juni-November adalah Musim Kemarau di mana suhu tetap pada rata-rata $31-33 \stackrel{\circ}{\circ}$, kelembaban terletak pada rata-rata $60-65 \%$ dan curah hujan adalah pada tingkat minimum.

Berdasarkan tabel di atas,menunjukkan bahwa kasus DBD semakin berkurand dari bulan Juni hingga ke bulan November. Salah satu faktor yang menyebabkan penurunan pada kasus adalah 2 musim di Bali iaitu musim hujan dan musim panas. Berdasarkan penelitian menunjukkan dari bulan Juni hingga November adalah musim kemarau. Rata-rata curah hujan adalah dari 12-108 mm pada bulan Juni November. Jika dibandingkan rata-rata curah hujan adalah 90-350 mm pada bulan Januari - Juli. Kurangnya takungan air pada musim kemarau menyebaban penurunan pada pembiakan nyamuk denggi. Penunuran pembiakan nyamuk menunjukkan penurunan pada kasus DBD.

\section{Bar Chart Demam Berdarah Dengue periode Juni hingga Nop 2014}

Grafik batang dibuat dasarkan data yang telah diambil dari RSUP Sanglah dari bulan Juni hingga 
November. Interpretasi yang dapat dilihat adalah kasus demam berdarah dengue menurun langkah demi langkah.

Bagan 5.1 Bar chart kasus DBD

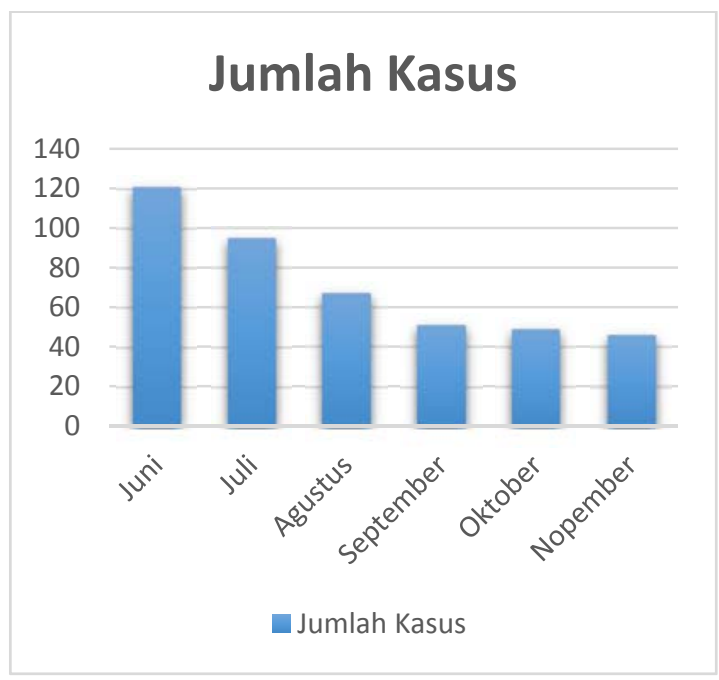

Berdasarkan hasil penelitian ini didapatkan bahwa persentase kasus tertinggi adalah pada bulan Juni dengan $28.20 \%$. Persentase ini diikuti dengan Juli sebanyak $22.14 \%$, Agustus sebanyak $15.62 \%$, September sebanyak $11.89 \%$, Oktober sebanyak $11.42 \%$, dan hanya $10.73 \%$ pada bulan November.

Hasil penelitian juga menunjukkan jumlah kasus yang telah dilaporkan jauh berbeda jika dibandingkan dengan jumlah kasus yang berlaku pada tahun 2013.Jumlah kasus yang terlapor dari bulan Januari-Juni tahun 2013 adalah sebanyak 1892 kasus.

\section{Distribusi Proporsi Kasus Dengue Berdasarkan Tempat Tinggal}

Proporsi penderita Demam Berdarah Dengue berdasarkan tempat tinggal terdapat paling tinggi pada kategori penderita yang bertempat tinggal di Bali dengan proporsi sebesar 98,84\%, dan paling rendah pada penderita yang bertempat tinggal di luar Bali dengan proporsi sebesar 1,16\%. RSUP Sanglah Denpasar adalah rumah sakit negeri kelas $A$ yang menjadi tempat rujukan Indonesia Tengah, Tidur, dan Timor Leste.

\section{Distribusi Proporsi Kasus Dengue Berdasarkan Jenis Kelamin}

Distribusi proporsi penderita Demam Berdarah Dengue berdasarkan jenis kelamin terdapat lebih banyak pada jenis kelamin laki-laki dengan proporsi sebesar $55.47 \%$ dibandingkan jenis kelamin perempuan yang proporsinya sebesar $44.53 \%$.Tidak ada sebarang hubungan signifikasi antara proporsi penderita laki-laki dan perempuan.

\section{Distribusi Proporsi Kasus Dengue Berdasarkan Jenis Perawatan}

Rawat inap (opname) adalah istilah yang berarti proses perawatan pasien oleh tenaga kesehatan profesional akibat penyakit tertentu, di mana pasien diinapkan di suatu ruangan di rumah sakit. Rawat jalan adalah pelayanan medis kepada seorang pasien untuk tujuan pengamatan, diagnosis, pengobatan, rehabilitasi, dan pelayanan kesehatan lainnya.

Indikasi rawat inap adalah jika pasien dating ke rumah sakit dengan kasus demam berdarah dengue dengan syok, disertai atau tidak pendarahan. Kasus DBD dengan pendarahan masif atau tidak dan juga kasus DBD tanpa pendarahan dengan trombosit $<100.00 / \mathrm{mm}$.

Distribusi proporsi penderita Demam Berdarah Dengue berdasarkan jenis perawatan terdapat lebih banyak pada jenis perawatan inap dengan proporsi sebesar $72.49 \%$ dibandingkan jenis perawatan jalan yang proporsinya sebesar $44.53 \%$.

Ini adalah disebabkan oleh karekteristik DBD pada fasa kritis yang menyebabkan suhu turun ke 37.5-38 darjah atau kurang dan tetap di bawah tingkat ini, biasanya pada hari 3-7 sakit, permeabilitas kapiler meningkat secara paralel dengan peningkatan kadar hematokrit dapat terjadi. Leukopenia progresif diikuti oleh penurunan cepat dalam jumlah trombosit biasanya mendahului kebocoran plasma. Pada titik ini pasien permeabilitas kapiler akan meningkat, sementara mereka dengan peningkatan permeabilitas kapiler dapat menjadi lebih buruk sebagai akibat dari volume plasma yang hilang. Syok terjadi ketika volume kritis plasma hilang melalui kebocoran. Dengan syok berkepanjangan, hipo organ hasil perfusi konsekuen dalam gangguan organ progresif, asidosis metabolik dan koagulasi intravaskular. Hal ini pada gilirannya menyebabkan perdarahan yang parah menyebabkan hematokrit menurun shock berat. Alih-alih leukopenia biasanya terlihat selama fase ini. Selain itu, gangguan organ berat seperti hepatitis berat, ensefalitis atau miokarditis dan / atau pendarahan parah juga dapat berkembang tanpa kebocoran plasma yang jelas atau syok.

\section{Distribusi Proporsi Penderita Demam Berdarah Dengue Berdasarkan Umur}

Berdasarkan hasil penelitian ini didapatkan data bahwa dari 429 data rekam medis penderita DBD di RSUP 
Sanglah Denpasar persentase penderita terbanyak adalah kelompok umur 20-40 tahun berjumlah 247 orang (57.58\%), disusul kelompok umur kurang dari 20 tahun berjumlah 128 orang (29.83\%), dan kelompok umur 40 tahun ke atas berjumlah 53 orang (12.59\%).

\section{Simpulan}

Hasil penelitian seterusnya diinterpretasi dalam bentuk bar chart. Interpretasi menunjukkan bahawa prevalensi demam berdarah dengue yang dilaporkan di RSUP Sanglah dari bulan Juni - November 2014 semakin berkurang langkah demi langkah.

Hasil penelitian juga menunjukkan jumlah kasus yang telah dilaporkan jauh berbeda jika dibandingkan dengan jumlah kasus yang berlaku pada tahun 2013.

\section{Saran}

\section{Bagi Masyarakat}

Disarankan untuk segera berkonsultasi dengan dokter perihal jika mencurigai mempunyai sebarang gejala demam berdarah dengue.

\section{Bagi Institusi}

a) Diharapkan Rumah Sakit Umum Pusat Sanglah untuk tetap meningkatkan pengawasan, keteraturan penggunaan DDT(gas yang digunakan untuk membunuh nyamuk) di area perumahan yang terjadi kasus dengue.

b) Diharapkan kepada petugas rekam medis Rumah Sakit Umum Pusat Sanglah untuk melengkapi pencatatan dan mengordinasikan data juga dari puskesmas untuk mendapatkan prevalensi yang lebih tepat.

\section{Bagi Peneliti Lain}

Perlu dilakukan penelitian lanjutan dengan menggunakan rekam medis jangka masa yang lebih panjang dan variabel yang lebih banyak.

\section{Ucapan Terima Kasih}

Puji syukur penulis panjatkan ke hadirat Tuhan Yang Maha Esa, karena atas berkat rahmat-Nya Usulan Penelitian dengan judul "Prevalensi Kasus Demam Berdarah Dengue di Rumah Sakit Umum Pusat Sanglah Denpasar" dapat selesai tepat pada waktu yang telah ditentukan.

Penulis menyadari bahwa tanpa bantuan dan bimbingan oleh semua pihak dari awal masa perkuliahan sampai dengan penyelesaian skripsi ini, akan sulit bagi penulis untuk dapat sampai pada akhir penyelesaian skripsi ini. Dalam kesempatan ini, Penulis ingin mengucapkan terima kasih yang sebesarbesarnya kepada:
1. DR.dr. I Wayan Putu Sutirtayasa, M.Si, selaku ketua Blok Special Study atas bantuan materi studi yang telah diberikan

2. dr. Putu Ayu Asri Damayanti, M.Kes., selaku sekretaris Blok Special Study atas bantuan arahannya dalam pembuatan skripsi

3. Dr. dr. Bagus Komang Satriyasa, M.Repro., Selaku pembimbing utama yang dengan penuh perhatian telah memberikan dorongan, semangat, bimbingan, dan saran selama penulis menyelesaikan skripsi ini.

4. Direktur Rumah Sakit Umum Pusat Sanglah yang telah memberi izin untuk melakukan penelitian di Rumah Sakit Umum Pusat Sanglah.

5. Kepala Instalasi Rekam Medis serta para pegawai di bagian Instalasi Rekam Medis Rumah Sakit Umum Pusat Sanglah yang telah banyak membantu dalam pengumpulan data.

6. Rekan-rekan mahasiswa Fakultas Kedokteran Universitas Udayana yang telah memberikan bantuan moral dan material dalam penyusunan skripsi ini

Akhir kata semoga Tuhan Yang Maha Esa membalas segala kebaikan dari semua pihak yang telah membantu pelaksanaan dan penyelesaian skripsi ini. Semoga skripsi ini dapat bermanfaat bagi semua pihak dan memberikan informasi bagi pengembangan ilmu pengetahuan di masa yang akan datang.

\section{DAFTAR PUSTAKA}

1. Bandyopadhyay S, Lum LC, Kroeger A.2006. Classifying dengue: a review of the Difficulties in using the WHO case classification for dengue haemorrhagic fever. Tropical Medicine and International Health, 11(8):1238--1255.

2. Anderson $\mathrm{K}$ et al. 2007.Burden of symptomatic dengue infection in children at Primary school in Thailand: a prospective study. Lancet, 369(9571):1452--1459.

3. Taylor MA et al.2006 Adapting to dengue risk Assessments of Impacts and AdaptationsTo Climate Change, (AIACC Working Paper No.33)

http://www.aiaccproject.org/working_papers LWorking\%20Papers/

AIACC_WP33_Taylor.pdf.

4. The Jakarta post 30.12.2013

http://www.thejakartapost.com/balidaily/2013-12-30/bali-has-highest-numberdengue-cases.html.

5. Parks W, Lloyd LS.2004 Planning social mobilization and communication for dengue fever prevention and control: a step-by-step guide. Geneva, World Health Organization, http://www.who.int/tdr/publications/publica 
tions/pdf/planning_dengue.pdf; accessed October 2008).

6. WHO. 2005 Guidelines for conducting a review of a national dengue prevention and Control programme. Geneva, World Health Organization, 2005 (Document WHO/CDS/CPE/PVC/2005.13).

7. Notoadmodjo, S, 2002, Metodologi Penelitian Kesehatan, Rineka Cipta, Jakarta. (buku)

8. Simmons JS, St. John JH, Reynolds FHK. Experimental studies of dengue. Philippine Journal of Science. 1931;44:1-251.

9. Centers for Disease Control and Prevention. CDC Dengue Fever home page. 2005. [cited 2007 Mar 21]. Available from http://www.cdc.gov/ncidod/dvbid/dengue/in dex.htm.

10. Kuno G. Review of the factors modulating dengue transmission.Epidemiol Rev. 2007;17:321-35.

11. Vasconcelos PF, Lima JW, da Rosa AP, Timbo MJ, da Rosa ES, Lima HR, et al. Dengue epidemic in Fortaleza, Ceara: randomized seroepidemiologic survey. Rev Saude Publica. 1998;32:447-54.

12. Gubler DJ. Epidemic dengue/dengue hemorrhagic fever as a public health, social and economic problem in the 21st century. Trends Microbiol.2010;10:100-3. 